\title{
ANALISIS PENGARUH SEKTOR UNGGULAN MENJADI PUSAT PERTUMBUHAN KABUPATEN LABUHANBATU TAHUN 2013-2017
}

\author{
Zulkarnain Nasution \\ Dosen Tetap Fakultas Ekonomi Dan Bisnis Universitas Labuhanbatu \\ Zulkarnainnasution1974@gmail.com
}

\begin{abstract}
Abstrak
Penelitian ini bertujuan untuk mengetahui sektor unggulan perekonomian daerah Kabupaten Labuhanbatu. Penelitian ini menggunakan data sekunder berupa runtun waktu (time series) dari Produk Domestik Regional Bruto (PDRB) Kabupaten Labuhanbatu dan Provinsi Sumatera Utara Tahun 2013-2017. Beberapa metode yang menggunakan data PDRB sebagai penentu sektor unggulan adalah metode Tipologi Klassen, LQ, Shift Share dan MRP. Metode-metode ini mengklasifikasikan sektor-sektor ekonomimenjadi empat yaitu sektor unggulan, sektor berkembang, sektor potensial dan sektor tertinggal, berdasarkan besarnya kontribusi dan laju pertumbuhannya. Dengan mengambil wilayah studi Kabupaten Labuhanbatu dan wilayah referensi Propinsi Sumatera Utara, maka dengan metode-metode tersebut dapat diketahui sektor mana yang menjadi sektor unggulan Kabupaten Labuhanbatu. Berdasarkan hasil yang diperoleh dari analisa beberapa metode tersebut, didapat hasil yang sama tentang sektor yang menjadi sektor unggulan di Kabupaten Labuhanbatu yaitu sektor industri pengolahan, sektor transportasi dan pergudangan, sektor penyediaan akumodasi dan makan minum, sektor keuangan dan asuransi serta sektor pendidikan.
\end{abstract}

\section{Kata Kunci: Sektor Unggulanpusat pertumbuhan ,tipologi kalssen, Location Quotient, Shift Share dan MRP.}

Abstract This study aims to determine the dominant sector of the regional economy Labuhanbatu. Secondary data were obtained the form of time series from the Gross Regional Domestic Product (GRDP) of Labuhanbatu and North Sumatera province from 2013-2017 to determine the most prominent sector using Typology Klassen, LQ, shift and MRP methods. The economic sectors were divided into four groups based on their large contribution and economic growth rate namely prominent, growing, potential and underdeveloped. The result showed that the Labuhanbatu and North Sumatera province were prominent in the agriculture, mining and quarrying, Transportation and Storage, Accommodation and Food Service Activities, financial, communication, and education sector.

\section{Pendahuluan}

Pembangunan sepertinya sebagai suatu fenomena yang tidak habis-habisnya dibahas dalam kerangka kajian keberlangsungan hidup manusia. Fenomena ini melekat sebagai salah satu ciri kehidupan manusia yang kerap mengalami perubahan menurut berbagai dimensi yang ada.

Konsep pembangunan biasanya melekat dalam konteks kajian suatu perubahan, pembangunan disini diartikan sebagaiu bentuk perubahan yang sifatnya direncanakan; setiap orang atau kelompok orang tentu akan mengharapkan perubahan yang mempunyai bentuk lebih baik 
bahkan sempurna dari keadaan yang sebelumnya; untuk mewujudkan harapan ini tentu harus memerlukan suatu perencanaan. Selo Soemardjan (1974) menyatakan bahwa perubahan yang dikehendaki atau direncanakan merupakan perubahan yang diperkirakan atau yang telah direncanakan terlebih dahulu oleh fihak-fihak yang hendak mengadakan perubahan di dalam masyarakat (Soemardjan-Soemardi, 1974: 490).

Pemerintah Daerah Kabupaten Labuhanbatu perlu melakukan prioritas kebijakan agar pembangunan daerah dapat berjalan sesuai rencana, baik kebijakan anggaran maupun pengeluaran daerah. Penentuan prioritas kebijakan tersebut dapat diwujudkan salah satunya dengan menentukan sektor prioritas atau unggulan dan melihat pertumbuhan dan perkembangannya. Pertumbuhan sektor ekonomi kabupaten dapat diklasifikasikan berdasarkan laju pertumbuhan dan kontribusi PDRB dari masing-masing sektor. Pertumbuhan sektor perekonomian yang ada di Kabupaten Labuhanbatu sangat berbeda pada masing-masing sektor, untuk itu perlu dilihat perkembangan sektor ekonomi berdasarkan laju pertumbuhan dan kontribusi PDRB setiap sektor tersebut. Hal ini juga diperlukan untuk pengalokasian dana sektor ekonomi dan untuk mengetahui klasifikasi/pola pertumbuhan dari sektor-sektor ekonomi yang ada sebagai pertimbangan untuk menentukan sektor unggulan yang dapat diprioritaskan di Kabupaten Labuhanbatu. Bagaimana pola pertumbuhan sektor-sektor ekonomi Kabupaten Labuhanbatu. Adanya perubahan konstribusi sektor-sektor perekonomian terhadap pembentukan PDRB Kabupaten Labuhanbatu serta apakah perubahan struktur ekonomi bertampak terhadap indikator kemajuan daerah. Sumberdaya alam yang ada di tiap daerah yang berbeda-beda pasti memiliki peran untuk masyarakat sekitarnya asalkan masyarakat mau menggali potensi yang ada didaerahnya dan memanfaatkan dengan sebaikbaiknya tanpa merusak lingkungan sekitar. Pertanyaannya adalah sektor apa yang menjadi unggulan untuk meningkatkan perekonomian wilayah di Kabupaten Labuhanbatu dan bagaimana perubahan sektor ekonomi terhadap PDRB Kabupaten Labuhanbatu serta dampaknya terhadap indikator kemajuan daerah 
Tabel 1. Produk Domestik Regional Bruto Kabupaten Labuhabatu Atas Dasar Harga Konstan Menurut Lapangan Usaha Tahun 2013-2017 (Juta Rp)

\begin{tabular}{|c|c|c|c|c|c|}
\hline \multirow{2}{*}{ PDRB 17 Sektor } & \multicolumn{5}{|c|}{$\begin{array}{l}\text { PDRB Menurut Lapangan Usaha Atas Dasar Harga Konstan } 2010 \\
\text { (Juta Rupiah) }\end{array}$} \\
\hline & 2013 & 2014 & 2015 & 2016 & 2017 \\
\hline $\begin{array}{l}\text { Pertanian, Kehutanan, dan } \\
\text { Perikanan }\end{array}$ & 4991548.65 & 5227484.96 & 5483729.75 & 5741133.44 & 5992487.63 \\
\hline Pertambangan dan Penggalian & 122572.01 & 129899.37 & 136837.20 & 143829.57 & 151051.74 \\
\hline Industri Pengolahan & 5753817.14 & 6024418.07 & 6325266.50 & 6652975.30 & 6947281.45 \\
\hline Pengadaan Listrik dan Gas & 13155.49 & 14147.26 & 15077.55 & 15799.35 & 16421.79 \\
\hline 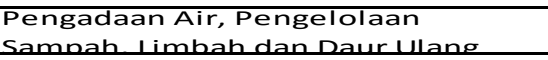 & 5874.08 .00 & 6089.07 .00 & 6340.72 & 6475.78 & 6908.02 .00 \\
\hline Konstruksi & 1392427.40 & 1477114.83 & 1555006.70 & 1649862.11 & 1761881.80 \\
\hline $\begin{array}{l}\text { Perdagangan Besar dan Eceran; } \\
\text { Reoarasi_Mob_dan_Seneda_Motor }\end{array}$ & 2767149.23 & 2930067.46 & 3067025.39 & 3229766.69 & 3422128.44 \\
\hline Transportasi dan Pergudangan & 284178.68 & 302298.77 & 319776.07 & 319776.07 & 338877.92 \\
\hline $\begin{array}{l}\text { Penyediaan Akomodasi dan Makan } \\
\text { Minum. }\end{array}$ & 236223.31 & 252075.94 & 267720.95 & 338877.92 & 367877.57 \\
\hline Informasi dan Komunikasi & 140928.94 & 149274.75 & 157900.33 & 167216.45 & 181545.08 \\
\hline Jasa Keuangan dan Asuransi & 210637.52 & 222427.48 & 235387.11 & 251191.12 & 253286.44 \\
\hline Real Estate & 432418.25 & 455898.56 & 479071.45 & 499671.52 & 537431.89 \\
\hline Jasa Perusahaan & 27362.24 & 28733.08 & 30130.12 & 31488.98 & 33838.14 \\
\hline $\begin{array}{l}\text { Administrasi Pemerintahan, } \\
\text { Pertahanandan daminan_Sosial }\end{array}$ & 490592.31 & 521597.74 & 555230.29 & 565724.14 & 579964.79 \\
\hline Jasa Pendidikan & 298956.88 & 321886.87 & 341461.49 & 360924.79 & 378727.65 \\
\hline Jasa Kesehatan dan Kegaiatan Sosial & 78594.52 & 83961.74 & 86532.95 & 88263.61 & 92008.19 \\
\hline Jasa Lainnya & 16975.27 & 17725.58 & 18500.15 & 19258.66 & 20213.80 \\
\hline Produk Domestik Regional Bruto & 17263411.92 & 18165101.54 & 19080994.74 & 20046019.12 & 21048165.60 \\
\hline
\end{tabular}

Sumber: www.Badan Pusat Statistik.go.id. Proyeksi diolah penulis sendiri.

Perbedaan penelitian terdahulu atau relefansi penulisan terletak pada alat analisis yang digunakan pada penelitian terdahulu serta lokasi penelitian menggunakan alat analisis Tipologi Klassen, Analisis Loqution Qoution, Analisis Shift Share, Analisis Model Rasio Pertumbuhan (MRP).

\section{Teori Kutub Pertumbuhan Ekonomi}

Perroux mendefinisikan kutub pertumbuhan regional sebagai seperangkat industriindustri sedang berkembang yang berlokasi di suatu daerah perkotaan dan mendorong perkembangan regional terdiri dari satu kumpulan industri-industri yang mengalami kemajuan dan saling berhubungan, serta cenderung menimbulkan aglomerasi yang di sebabkan oleh adanya faktor-faktor ekonomi eksternal. Faktor-faktor eksternal itu seperti turunnya biaya produksi, pembangunan pasar bagi pekerja urban dan akses pasar yang lebih besar (Sitohang,2001:98).

\section{Teori Basis Ekonomi}

Model basis ekonomi menyatakan bahwa faktor penentu utama pertumbuhan ekonomi suatu daerah keuntungan kompetitif yang berhubungan langsung dengan permintaan barang dan jasa dari luar daerah. Berdasarkan teori ini perekonomian suatu wilayah dibagi menjadi dua yaitu sektor basis dan sektor non basis. Sektor basis adalah Sektor yang menjadi tulang punggung perekonomian daerah karena memepunyai keuntungan kompetitif yang cukup tinggi, sehingga mampu mengekspor barang dan jasa ke luar batas-batas perekonomian wilayah yang bersangkutan. Sedangkan sektor non basis merupakan kegiatan-kegiatan yang menyediakan barang dan jasa untuk memenuhi kebutuhan orang-orang yang bertempat tinggal di dalam batas-batas perekonomian wilayah tersebut. Sektor non basis ini berfungsi sebagai sektor penunjang sektor basis atau service industries (Sjafrizal, 2008). Teori Basis basis 
ekonomi menyatakan salah satu faktor pertumbuhan ekonomi daerah berhubungan langsung dengan permintaan barang dan jasa dari luar daerah (Hasani, 2010).

3. Sektor Unggulan

Sektor unggulan adalah sktor yang dapat dikembangkan lebih lanjut dan bertujuan untuk meningkatkan prtumbuhan ekonomi suatu wilayah. Sektor unggulan terbentuk dari pengembangan produksi yang dihasilkan oleh potensi yang dimiliki daerah. Sektor unggulan tersebut bukan hanya mampu untuk memenuhi permintaan dari dalam daerah nya saja namun juga mampu untuk memenuhi permintaan dari luar daerahnya. Dikatakan sektor unggulan apabila sektor tersebut memiliki keunggulan baik secara komparatif maupun secara kompetitif (Erawati, 2011).

4. Teori Pergeseran Struktur Ekonomi

Teori perubahan struktural (Struktural Change Theory), merupakan teori yang menjelaskan tentang transformasi struktur perekonomian yaitu dari sektor pertanian (Tradisional) menuju sektor yang lebih modern serta memiliki sektor jasa-jasa dan sektor industri manufaktur yang lebih tangguh. Teori-teori perubahan struktral (Structural-Change Theory) memusatkan perhatian pada transformasi struktur ekonomi dari pola pertanian ke struktur yang lebih modern serta memiliki sektor industri manufaktur dan sektor jasa-jasa yang tangguh. Aliran pendekatan struktural ini didukung oleh W.Arthur Lewis yang terkenal dengan model teoritisnya tentang "Surplus Tenaga Kerja Dua Sektor" (Two Sector Surplus Labor) dan Hollis B. Chenery yang sangat terkenal dengan analisis empirisnya tentang "Pola-pola Pembangunan" (Pattern Of Development) (Todaro, 2000).

5. Spesialisasi Perekonomian

Perekonomian suatu wilayah dapat dikatakan terspesialisasi jika suatu willayah memprioritaskan pengembangan suatu sektor ekonomi melalui kebijakan-kebijakan yang mendukung terhadap kemajuan sektor tersebut. Pengembangan sektor prioritas tersebut dapat dilakukan melalui investasi dan peningkatan sumber daya manusia pada sektor tersebut. Menurut (Kuncoro, 2002), salah satu upaya yang dapat ditempuh untuk meningkatkan keterkaitan antar wilayah adalah melalui proses pertukaran komditas antar daerah. Hal ini dapat ditempuh melalui penciptaan spesialisasi antar daerah.

\section{METODOLOGI}

\section{Lokasi dan Waktu Penelitian}

Penelitian dilakukan di Kabupaten Labuhanbatu, Provinsi Sumatera Utara. Penelitian ini dilaksanakan pada bulan Oktober sampai dengan Desember 2019. Pemilihan lokasi penelitian di Kabupaten Labuhanbatu dipilih secara purposive, dengan pertimbangan bahwa Kabupaten Labuhanbatu merupakan kabupaten yang mempunyai potensi sumberdaya alam yang dapat dikelola untuk meningkatkan perekonomian dan pembangunan wilayah.

\section{Jenis dan Sumber Data}

Jenis data yang digunakan dalam penelitian ini adalah data sekunder yang diperoleh dari Badan Pusat Statistik (BPS) Kabupaten Labuhanbatu, Badan Perencanaan Pembangunan Daerah (BAPPEDA) Kabupaten Labuhanbatu, publikasi beberapa penelitian terdahulu, jurnal, artikel, dan internet. Keseluruhan data yang diperlukan untuk analisis pertumbuhan sektor ekonomi wilayah dan sektor unggulan Kabupaten Labuhanbatu adalah: (1) PDRB Kabupaten Labuhanbatu; (2) laju pertumbuhan dan kontribusi PDRB Provinsi Sumatera Utara dan Indikator Tingkat Kesejahteraan Kabupaten Labuhanbatu; (3) Data potensi ekonomi Kabupaten Labuhanbatu, serta berbagai macam data sekunder lainnya. 


\section{Metode Analisis Data}

Alat analisis yang digunakan dalam studi penelitian ini secara umum terdiri atas tiga metode, yaitu: analisis pola pertumbuhan sektor ekonomi (Klassen Typologi), analisis Location Quotient, dan analisis skalogram. Pengolahan data dari ketiga metode/alat analisis yang digunakan dalam penelitian ini diolah dengan menggunakan program Microsoft Excel

\section{Analisis Pola Pertumbuhan Ekonomi Sektoral}

Pola pertumbuhan sektor ekonomi wilayah dapat di tentukan dengan analisis Klassen Typologi dengan pendekatan sektoral yang diamati dengan menggabungkan secara sistematis terhadap laju pertumbuhan PDRB dan kontribusi PDRB per sektor, dan setelah itu diklasifikasikan kedalam kelompok/karakteristik menurut Klassen Typologi. Dengan analisis Klassen Typologi dapat diketahui empat klasifikasi pertumbuhan sektor ekonomi, yaitu sektor yang maju dan tumbuh cepat, sektor maju tapi tertekan, sektor potensial atau masih dapat berkembang dengan pesat (sedang tumbuh), dan sektor yang relatif tertinggal

Klasifikasi Klassen Typologi Pendekatan Sektoral:

\begin{tabular}{|c|c|c|}
\hline & si $>\boldsymbol{s}$ & $s \boldsymbol{i} \boldsymbol{s}$ \\
\hline $\boldsymbol{g} \boldsymbol{i}>\boldsymbol{g}$ & Sektor maju dan tumbuh cepat & $\begin{array}{c}\text { Sektor berkembang cepat } \\
\text { (potensial) }\end{array}$ \\
\hline $\boldsymbol{g i}<\boldsymbol{g}$ & Sektor maju tapi tertekan & Sektor relatif tertinggal \\
\hline
\end{tabular}

Keterangan:

gi : Laju pertumbuhan PDRB sektoral kabupaten i

si : Kontribusi PDRB sektoral kabupaten i

$\mathrm{g}$ : Laju pertumbuhan PDRB sektoral Provinsi Sumatera Utara

s : Kontribusi PDRB sektoral Provinsi Sumatera Utara

\section{Analisis Location Quotient}

Location Quotient (LQ) merupakan perbandingan besarnya peranan suatu sektor di suatu daerah terhadap besarnya peranan sektor tersebut secara nasional. Teknik LQ mengasumsikan: (1) adanya sedikit variasi dalam pola pengeluaran secara geografis; (2) produktivitas tenaga kerja adalah homogen (sama); (3) setiap industri menghasilkan barang yang sejenis didalam sektor yang bersangkutan. Nilai LQ merupakan indeks untuk membandingkan pangsa sub wilayah dalam aktivitas tertentu dengan pangsa total aktivitas tersebut secara total. LQ didefinisikan sebagai rasio persentase dari total aktivitas pada sub wilayah ke i terhadap persentase aktivitas total terhadap wilayah yang diamati.

$$
L Q A=\frac{S_{1} / N_{1}}{S / N}
$$

Dimana:

LQ : Besarnya koefisien lokasi suatu sektor Ekonomi

$S$ : PDRB sektor $i$ di Kabupaten Labuhanbatu

Ni : Total PDRB di Provinsi Sumatera Utara $j$

$\mathrm{N}$ : Total PDRB di Kabupaten Labuhanbatu

Kriterianya adalah :

1. Jika LQ > 1 maka komoditas tersebut dapat dikatakan sebagai komoditas basic atau unggulan, sehingga perekonomian di suatu kecamatan memiliki kesempatan lebih besar 
untuk memenuhi kebutuhan daerah akan produk-produk dengan komoditas-komoditas sendiri.

2. Jika LQ $<1$ maka komoditas tersebut bukan merupakan komoditas basic atau unggulan sehingga dapat dikatakan kecamatan tersebut kekurangan produk atas komoditas tersebut dan harus mendatangkan dari daerah lain.

3. Jika LQ = 1 maka komoditas tersebut mempunyai kontribusi hanya cukup untuk memenuhi kebutuhannya sendiri tanpa mampu memenuhi permintaan komoditas tersebut dari luar.

Analisis Shift-share

Alat analisis yang dipakai untuk menjawab tujuan kedua adalah Analisis Shift-share dengan rumus (Tarigan, 2005: 88):

$\Delta E_{\mathrm{r}, \mathrm{i}, \mathrm{t}}=\left(N s_{i}+P_{r, i}+D_{r, i}\right)$

dimana $\Delta E_{\mathrm{r}, \mathrm{i}, \mathrm{t}}$ adalah tambahan semua sektor; $N s_{i}$ adalah National Share; $P_{r, i}$ adalah Proportional Shift; dan $D_{r, i}$ adalah Differential Shift.

Alat analisis yang dipakai untuk menjawab tujuan ketiga yaitu mencari nilai Proyeksi PDRB Jawa Timur adalah Penjumlahan Proyeksi National Share, Proportional Share, dan Differential Shift. Ketiga proyeksi tersebut bisa digabung dalam bentuk proyeksi langsung (Tarigan, 2005: 89-90):

$E_{\mathrm{r}, \mathrm{i}, \mathrm{t}+\mathrm{m}}=E_{, \mathrm{r}, \mathrm{i}, \mathrm{t}}\left\{\frac{\mathrm{En, \textrm {i } , \mathrm { t } + \mathrm { m }}}{\mathrm{En}, \mathrm{i}, \mathrm{t}}+\frac{m}{n}+\frac{\mathrm{Dr}, \mathrm{i}, \mathrm{t}}{\mathrm{Er}, \mathrm{i}, \mathrm{t}-\mathrm{n}}\right\}$

\section{HASIL DAN PEMBAHASAN}

\section{Identifikasi Pola Pertumbuhan Ekonomi Sektoral Kabupaten Labuhanbatu}

Kabupaten Labuhanbatu adalah salah satu kabupaten yang ada diprovinsi Sumatera Utara kabupaten ini terletak di Rantauprapat. Kabupaten Labuhanbatu terkenal dengan hasil perkebunan kelapa sawit dan karet. Kabupaten Labuhanbatu mempunyai kedudukan yang cukup strategis, yaitu berada pada jalur lintas timur Sumatra dan berada pada persimpangan menuju Provinsi Sumatra Barat dan Riau yang menghubungkan pusat-pusat perkembangan wilayah di Sumatra dan Jawa serta mempunyai akses yang memadai ke luar negeri karena berbatasan langsung dengan Selat Malaka

Pada tahun 2008 kabupaten Labuhanbatu mengalami pemekaran wilayah menjadi 3 kabupaten yaitu Kabupaten Labuhanbatu, Kabupaten Labuhanbatu Selatan dan Kabupaten Labuhanbatu Utara. Setelah pemekaran wilayah tersebut, Kabupaten Labuhanbatu hanya terdiri dari 9 Kecamatan, Bilah Hulu, Pangkatan, Bilah Barat, Bilah Hilir, Panai Hulu, Panai Tengah, Panai Hilir, Rantau Selatan, Rantau Utara

Berdasarkan Klassen Typologi, pola pertumbuhan sektor ekonomi yang dapat dikategorikan sebagai sektor maju dan tumbuh cepat adalah sektor kontruksi dan informasi komunikasi. Sektor inilah yang sebaiknya mendapat perhatian yang lebih dari Pemerintah Daerah Kabupaten Labuhanbatu untuk dikembangkan. Sektor kontruksi dan informasi komunikasi mempunyai kinerja laju pertumbuhan dan kontribusi yang sama dengan Provinsi Sumatera Utara yaitu 6,79 persen rata-rata laju pertumbuhan dan 8,4 persen untuk kontribusi sektor informasi dan komunikasi terhadap PDRB Kabupaten Labuhanbatu. Klasifikasi pola pertumbuhan sektor ekonomi. 
Tabel 2. Laju Pertumbuhan dan Kontribusi PDRB

\begin{tabular}{|c|c|c|c|c|c|}
\hline \multirow[t]{2}{*}{ No } & \multirow[t]{2}{*}{ Lapangan Usaha } & \multicolumn{2}{|c|}{$\begin{array}{c}\text { Laju Pertumbuhan } \\
\text { PDRB Rata-Rata } \\
\text { (Persen) } \\
\end{array}$} & \multicolumn{2}{|c|}{$\begin{array}{c}\text { Kontribusi PDRB } \\
\text { Rata-Rata } \\
\text { (Persen) }\end{array}$} \\
\hline & & Sumut & \begin{tabular}{|c|}
$\begin{array}{c}\text { Labuhan } \\
\text { batu }\end{array}$ \\
\end{tabular} & Sumut & $\begin{array}{c}\text { Cabuhan } \\
\text { batu }\end{array}$ \\
\hline 1 & Pertanian, Kehutanan, dan Perikanan & 5,31 & 4,38 & 20,92 & 28,5 \\
\hline 2 & Pertambangan dan Penggalian & 4,81 & 5,02 & 1,29 & 0,7 \\
\hline 3 & Industri Pengolahan & 2,31 & 4,42 & 20,03 & 33 \\
\hline 4 & Pengadaan Listrik dan Gas & 8,72 & 3,94 & 0,11 & 0,1 \\
\hline 5 & $\begin{array}{l}\text { Pengadaan Air, Pengelolaan Sampah, } \\
\text { Limbah dan Daur Ulang }\end{array}$ & 6,67 & 6,67 & 0,1 & 0,03 \\
\hline 6 & Konstruksi & 6,79 & 6,79 & 13,89 & 8,4 \\
\hline 7 & \begin{tabular}{|l|} 
Perdagangan Besar dan Eceran; \\
Reparasi Mobil dan Sepeda Motor
\end{tabular} & 5,87 & 5,96 & 18,13 & 16,3 \\
\hline 8 & Transportasi dan Pergudangan & 7,35 & 8,56 & 5 & 1,6 \\
\hline 9 & $\begin{array}{l}\text { Penyediaan Akomodasi dan Makan } \\
\text { Minum }\end{array}$ & 7,32 & 7,6 & 2,38 & 1,7 \\
\hline 10 & Informasi dan Komunikasi & 8,57 & 8,57 & 2,04 & 0,9 \\
\hline 11 & Jasa Keuangan dan Asuransi & 0,49 & 0,83 & 3,05 & 1,2 \\
\hline 12 & Real Estate & 7,56 & 7,56 & 5,04 & 2,6 \\
\hline 13 & Jasa Perusahaan & 7,46 & 7,46 & 1,03 & 0,2 \\
\hline 14 & $\begin{array}{l}\text { Administrasi Pemerintahan, } \\
\text { Pertahanan dan Jaminan Sosial Wajib }\end{array}$ & 2,52 & 2,52 & 3,6 & 2,8 \\
\hline 15 & Jasa Pendidikan & 4,93 & 4,93 & 1,83 & 1,8 \\
\hline 16 & Jasa Kesehatan dan Kegaiatan Sosial & 7,64 & 4,24 & 0,98 & 0,4 \\
\hline 17 & Jasa Lainnya & 7,56 & 4,96 & 0,57 & 0,1 \\
\hline & Produk Domestik Regional Bruto & 5,12 & 5 & 100 & 100 \\
\hline
\end{tabular}

Sumber: www.Badan Pusat Statistik.go.id. Proyeksi diolah penulis sendiri.

Kabupaten Labuhanbatu menurut Klassen Typologi dapat dilihat pada Tabel diatas Sektor industri pengelolaan dan pertanian mempunyai peranan dalam penciptaan nilai tambah pada perekonomian Kabupaten Labuhanbatu yang dapat dilihat dari peningkatan distribusi PDRB Tiga lapangan usaha yang memberi peran dominan terhadap PDRB Labuhanbatu pada tahun 2017 yaitu: industri pengolahan sebesar 35,40 persen, pertanian, perikanan dan kehutanan sebesar 24,28 persen serta perdagangan besar dan eceran dan reperasi mobil dan sepeda motor sebesar 16,62 persen.

sektor pengadaan listrik dan gas dan penggalian dari tahun 2005 sebesar 4,96 persen meningkat tajam menjadi 9,22 persen pada tahun 2006. Rata-rata dari kontribusi sektor pertambangan dan penggalian di Kabupaten Labuhanbatu ini lebih besar daripada kontribusi sektor pertambangan dan penggalian di Provinsi Sumatera Utara, karena sumberdaya alam Kabupaten Labuhanbatu sangat berpotensi di subsektor perkebunan sawit. Selanjutnya adalah sektor industri pengolahan, yang termasuk kuadran I yaitu sektor maju dan tumbuh cepat. Sektor ini mempunyai kinerja kontribusi ekonomi yang lebih besar daripada Provinsi sumatera Utara yaitu 33 persen rata-rata kontribusi PDRB Kabupaten Labuhanbatu dan 20,03 persen untuk kontribusi sektor industri pengolahan terhadap PDRB Provinsi Sumatera Utara. Sektor 
pertambangan, sektor perdagangan besar, sektor tranportasi serta sektor akomodasi menjadi sektor di daerah Labuhanbatu termasuk kuadran II yaitu sektor berkembang cepat dibandingakan PDRB Propinsi Sumatera Utara. Sektor pertanian mempunyai kinerja laju pertumbuhan PDRB yang lebih kecil dibandingkan laju pertumbuhan PDRB sektor pertanian di Provinsi Sumatera Utara, yaitu sebesar 28,50 persen untuk Kabupaten labuhanbatu dan 20,92 persen untuk Provinsi Sumatera Utara sektor ini menjadi sektor maju tetapi tertekan.

\section{Analisis Sektor Unggulan di Kabupaten Labuhanbatu}

Penentuan sektor unggulan di Kabupaten Labuhanbatu adalah untuk lebih dapat meningkatkan pendapatan dan kesejahteraan masyarakat Labuhanbatu. Sektor unggulan atau sektor yang berpotensi dalam perekonomian di Kabupaten Labuhanbatu dapat diketahui dan dapat dikembangkan, karena mampu melayani pasar di daerah itu sendiri maupun diluar daerah yang bersangkutan yang tentunya akan mendapatkan surplus dari perkembangan sektor unggulan ini.

Tabel 3. Nilai LQ Sektor-Sektor Perekonomian di Kabupaten Labuhanbatu Berdasarkan Harga Konstan 2010 Periode 2013-2017

\begin{tabular}{|c|c|c|c|c|c|c|}
\hline \multirow{2}{*}{ No } & \multirow{2}{*}{ Sektor } & \multicolumn{5}{|c|}{ Tahun } \\
\hline & & 2013 & 2014 & 2015 & 2016 & 2017 \\
\hline 1 & $\begin{array}{l}\text { Pertanian, Kehutanan, dan } \\
\text { Perikanan }\end{array}$ & 1,41 & 1,24 & 0,29 & 0,9 & 1,12 \\
\hline 2 & Pertambangan dan Penggalian & 0,04 & 0,59 & 0,14 & 0,42 & 0,53 \\
\hline 3 & Industri Pengolahan & 0,07 & 1,79 & 4,23 & O,O1 & 1,69 \\
\hline 4 & Pengadaan Listrik dan Gas & 0,01 & 0,6 & 0,15 & 0,46 & 0,55 \\
\hline 5 & $\begin{array}{l}\text { Pengadaan Air; Pengelolaan } \\
\text { Sampah, Limbah, dan Daur }\end{array}$ & 0,21 & $\mathbf{O}$ & 0,09 & 0,26 & 0,33 \\
\hline 6 & Konstruksi & $\mathbf{O}, \mathbf{O 1}$ & 0,71 & 0,02 & 0,52 & 0,65 \\
\hline 7 & $\begin{array}{l}\text { Perdagangan Besar dan Eceran; } \\
\text { Reparasi Mobil dan Sepeda }\end{array}$ & 1,5 & 0,98 & 0,23 & 0,72 & 0,9 \\
\hline 8 & Transportasi dan Pergudangan & 0,12 & 0,39 & 0,09 & 0,27 & 0,33 \\
\hline 9 & Informasi dan Komunikasi & 0,34 & 0,6 & 0,14 & 0,51 & 0,64 \\
\hline 10 & Jasa Keuangan dan Asuransi & 0,43 & 0,28 & 0,07 & 0,21 & 0,28 \\
\hline 11 & Real Estat & 0,72 & 0,32 & 0,08 & 0,24 & 0,28 \\
\hline 12 & Jasa Perusahaan & 0,9 & 0,2 & 0,72 & 2,22 & 2,78 \\
\hline 13 & $\begin{array}{l}\text { Administrasi Pemerintahan, } \\
\text { Pertahanan, dan Jaminan Sosial }\end{array}$ & 0,04 & 0,05 & $\mathbf{O}, \mathbf{O 1}$ & O,04 & 0,05 \\
\hline 14 & Jasa Pendidikan & 2,31 & 1,52 & 0,36 & 1,1 & 1,34 \\
\hline 15 & $\begin{array}{l}\text { Jasa Kesehatan dan Kegiatan } \\
\text { Sosial }\end{array}$ & 0,59 & 0,55 & 0,49 & 1,5 & 1,82 \\
\hline 16 & Jasa Lainnya & 0,29 & 0,21 & 0,23 & 0,69 & 0,83 \\
\hline
\end{tabular}

Sumber: www.Badan Pusat Statistik.go.id. Proyeksi diolah penulis sendiri.

Dari Tabel di atas di ketahui bahwa tahun 2013 dan 2017:

LQ > 1, ada lima sektor yaitu: sektor pertanian, Industri Pengolahan; jasa perusahaan , jasa pendidikan, jasa kesehatan dan kegiatan sosial. Sektor-sektor ini disebut sektor basis (base sector) atau sektor komoditas.

LQ $<1$, ada dua belas sektor yaitu: A.Pertambangan dan Penggalian; D. Pengadaan Listrik dan Gas; Pengadaan Air; Pengelolaan Sampah, Limbah, dan Daur Ulang F. Kontruksi; H. Perdagangan Besar dan Eceran; Reparasi Mobil dan Sepeda Motor : Transportasi dan Perdagangan; K. Jasa Keuangan dan Asuransi; L. Real Estate; M,N. Jasa Perusahaan; O. 
Administrasi Pemerintahan, Pertahanan, Jaminan Sosial; ; dan R,S,T,U. Jasa Lainnya. Sektorsektor ini disebut sektor non-basis (non-base sector) atau sektor non-komoditas.

Catatan lain tentang nilai LQ untuk tahun 2013 adalah sektor yang akan menjadi mandiri adalah jasa perusahaan dengan skor 0,90 namun tahun 2017 sektor ini merupaka yang paling dominan dalam kemandirian sehingga menjadi sektor andalan dengan nilai LQ $=2,78$. Sektor yang paling kecil adalah sektor Pengadaan listrik dan Gas dan konstruksi dengan $L Q=0,01$. Pada tahun 2017 sektor yang akan mandiri adalah Perdagangan Besar dan Eceran; Reparasi Mobil dan Sepeda Motor dengan LQ $=0,90$. Sektor yang paling kecil adalah Administrasi Pemerintahan, Pertahanan, dan Jaminan Sosial Wajib tahun 2017.

\section{Analisis Shift-Share}

Untuk menunjuk-temukan sektor-sektor yang berkembang di suatu wilayah dibandingkan dengan perkembangan ekonomi nasional, digunakan teknik analisis shift-share. Teknik ini menggambarkan performance (kinerja) sektor-sektor di suatu wilayah dibandingkan dengan kinerja perekonomian nasional.

Tabel 4. Analisis shift share klasik Labuhanbatu 2013-2017 (Juta Rupiah)

\begin{tabular}{|c|c|c|c|c|c|}
\hline NO & SEKTOR & $\begin{array}{l}\text { NATIONAL } \\
\text { SHARE }\end{array}$ & $\begin{array}{l}\text { PROPORTIONAL } \\
\text { SHARE }\end{array}$ & $\begin{array}{l}\text { DEFERENSIAL } \\
\text { SHARE }\end{array}$ & SHIFT SHARE \\
\hline 1 & Pertanian, Kehutanan, dan Perikanan & 1104088,26 & $-10314928,11$ & $-6865313,978$ & $-16076153,8$ \\
\hline 2 & Pertambangan dan Penggalian & 271118, 89 & 136784,011 & $-42234,84912$ & 365668,0519 \\
\hline 3 & Industri Pengolahan & 1272695,59 & $-7923128,134$ & 32815602,35 & 26165169,81 \\
\hline 4 & Pengadaan Listrik dan Gas & 29098,82 & 35641,70966 & $-33821,51374$ & 30919,01592 \\
\hline 5 & $\begin{array}{l}\text { Pengadaan Air, Pengelolaan Sampah, } \\
\text { Limbah dan Daur Ulang }\end{array}$ & 12992,96 & $-26535,67168$ & $-56845,32121$ & $-70388,0329$ \\
\hline 6 & Konstruksi & 3079931,4 & 6146125,908 & $-744464,4709$ & 8481592,837 \\
\hline 7 & $\begin{array}{l}\text { Perdagangan Besar dan Eceran; } \\
\text { Reparasi Mobil dan Sepeda Motor }\end{array}$ & 6120699,59 & 4290925,02 & $-294244,3177$ & 10117380,29 \\
\hline 8 & Transportasi dan Pergudangan & 628579,15 & $-815867,5778$ & 30277727,17 & 30090438,74 \\
\hline 9 & $\begin{array}{l}\text { Penyediaan Akomodasi dan Makan } \\
\text { Minum }\end{array}$ & 522505,94 & 7940366,567 & 6025647,681 & 14488520,19 \\
\hline 10 & Informasi dan Komunikasi & 311722,87 & 944385,2757 & $-783123,5025$ & 472984,6432 \\
\hline 11 & Jasa Keuangan dan Asuransi & 4659123,44 & $-394231,4402$ & 1095576,426 & 5360468,426 \\
\hline 12 & Real Estate & 956472,52 & 936638,7576 & $-1780330,611$ & 112780,6666 \\
\hline 13 & Jasa Perusahaan & 60522,95 & 42360,439 & $-137058,5594$ & $-34175,1704$ \\
\hline 14 & $\begin{array}{l}\text { Administrasi Pemerintahan, } \\
\text { Pertahanan dan Jaminan Sosial Wajib }\end{array}$ & 108514,86 & $-1914238,151$ & $-626651,2931$ & $-2432374,58$ \\
\hline 15 & Jasa Pendidikan & 661267,28 & 1364404,162 & 1106745,619 & 3132417,061 \\
\hline 16 & Jasa Kesehatan dan Kegaiatan Sosial & 17384,44 & $-397077,1784$ & $-1191266,074$ & $-1570958,81$ \\
\hline 17 & Jasa Lainnya & 37547,85 & $-51625,58691$ & $-199334,8314$ & $-213412,568$ \\
\hline & & 38185204,2 & & & 78420877 \\
\hline
\end{tabular}

Sumber: www.Badan Pusat Statistik.go.id. Proyeksi diolah penulis sendiri.

Dari Tabel diatas diketahui bahwa sektor yang memiliki National share terbesar adalah sektor Perdagangan Besar dan Eceran; Reparasi Mobil dan Sepeda Motor sebesar 6120699,59, sedangkan yang terkecil adalah Pengadaan Air, Pengelolaan Sampah, Limbah dan Daur Ulang, Jasa Kesehatan dan Kegaiatan Sosial dengan angka 12992 dan 17384,44. Total National Share sebesar 38185204,2. Dari Tabel 4 diketahui angka Proportional Shift masih memiliki delapan sektor yang bernilai negatif yaitu: (1). Pertanian, Kehutanan, Perikanan; (2). Pertambangan dan Penggalian; (3). Pengadaan Listrik dan Gas; dan (4). Pengadaan Air, Pengelolaan Sampah, 
Limbah dan Daur Ulang , (5)Transportasi dan Pergudangan , (6)Jasa Keuangan dan Asuransi Administrasi Pemerintahan, Pertahanan dan Jaminan Sosial Wajib , (7)Jasa Kesehatan dan (8) Kegaiatan Sosial dan jasa Lainnya. Kedelapan sektor ini memiliki tingkat pertumbuhan di daerah lebih lambat dibandingkan provinsi. Hal ini terjadi karena pengaruh sektor i secara propinsi (ekstern) terhadap sektor i dalam PDRB Kabupaten Labuhanbatu .

Dari Tabel diatas ketahui bahwa nilai Differential Shift yang memiliki tanda negatif ada duabelas sektor. Sektor-sektor tersebut bisa diamati di dalam Tabel .Arti lebih lanjut, keduabelas sektor ini kurang menguntungkan dalam perkembangan Produk Domestik Regional Kabupaten Labuhanbatu secara intern.

Hasil analisis Shift Share menunjukkan bahwa selama tahun 2013-2017, nilai PDRB sektoral kabupaten Labuhanbatu telah mengalami perubahan atau perkembangan. Nilai PDRB tersebut tumbuh sebesar Rp 78.420.877. Perkembangan tersebut dipengaruhi oleh komponen pertumbuhan nasional (NS), bauran industri (PS), dan keunggulan kompetitif (DS).

\section{Analisis Marginal Rasio Pertumbuhan}

Analisis MRP merupakan alat analisis untuk melihat deskripsi kegiatan atau sektor ekonomi yang potensial berdasarkan pada kriteria pertumbuhan struktur ekonomi wilayah baik eksternal maupun internal.

Hasil Perhitungan MRP Kabupaten Kubu Raya Tahun 2013-2017

\begin{tabular}{|c|c|c|c|c|}
\hline SEKTOOR & SUMUT & NOMINAL & $\begin{array}{l}\text { LABUHAN } \\
\text { BATUU }\end{array}$ & NOMINAL \\
\hline $\begin{array}{l}\text { Pertanian, Kehutanan, dan } \\
\text { Perikanan }\end{array}$ & 1,25482 & + & 0,906575149 & - \\
\hline Industri Pengolahan & 0,88067 & - & 0,937745301 & - \\
\hline Pengadaan Listrik dan Gas & $-5,1098$ & - & 1,122485031 & + \\
\hline Konstruksi & 1,58508 & + & 1,199553986 & + \\
\hline $\begin{array}{l}\text { Perdagangan Besar dan Eceran; } \\
\text { Reparasi Mobil dan Sepeda }\end{array}$ & 1,39233 & + & 1,07010514 & + \\
\hline Transportasi dan Pergudangan & $-5,1121$ & - & 0,870204481 & - \\
\hline $\begin{array}{l}\text { Penyediaan Akomodasi dan } \\
\text { Makan Minum }\end{array}$ & 1,76995 & + & 2,519670096 & + \\
\hline Real Estate & 1,66324 & + & 1,097926363 & + \\
\hline Jasa Perusahaan & 1,67928 & + & 1,069990697 & + \\
\hline $\begin{array}{l}\text { Administrasi Pemerintahan, } \\
\text { Pertahanan dan Jaminan Sosial }\end{array}$ & 1,1416 & + & 0,823596683 & - \\
\hline Jasa Pendidikan & 1,34576 & + & 1,20633172 & + \\
\hline $\begin{array}{l}\text { Jasa Kesehatan dan Kegaiatan } \\
\text { Sosial }\end{array}$ & 1,88703 & + & 0,771590493 & - \\
\hline Jasa Lainnya & 1,80485 & + & 0,862507241 & - \\
\hline
\end{tabular}

Sumber: www.Badan Pusat Statistik.go.id. Proyeksi diolah penulis sendiri.

Model analisis ini diturunkan dari persamaan awal komponen utama dalam analisis Shift Share yaitu Differential Shift dan Proportionality Shift. Dalam analisis ini terdapat dua jenis rasio pertumbuhan yaitu Rasio Pertumbuhan Wilayah Referensi (RPR) yaitu Provinsi Sumatera Utara dan Rasio Pertumbuhan Wilayah Studi (RPS) yaitu Kabupaten Labuhanbatu .

Tabel diatas menyajikan hasil perhitungan dan analisis MRP Kabupaten Labuhanbatu untuk melihat deskripsi kegiatan atau sektor ekonomi terutama struktur ekonomi diwilayah ini. Hasil 
perhitungan tersebut menunjukkan bahwa sektor ekonomi yang mempunyai nilai RPR positif (+) dan nilai RPS positif (+) yaitu sektor pertambangan dan pengalian dan sektor kontruksi, sektor perdagangan besar dan eceran, sektor reparasi mobil dan sepeda motor, sektor penyediaan akomodasi dan makan minum, sektor informasi dan komunikasi dan sektor real estate, sektor jasa perusahaan dan sektor jasa pendidikan. Hal ini berarti pada periode tahun 2013-2017, merupakan sektor yang potensial baik ditingkat provinsi maupun di tingkat kabupaten karena mempunyai pertumbuhan yang menonjol dari sektor ekonomi yang lain.

Sektor ekonomi yang mempunyai nilai RPR positif (+) dan nilai RPS negatif (-) yaitu sektor Pertanian, Kehutanan, dan Perikanan, sektor Pengadaan Air, Pengelolaan Sampah, Limbah dan Daur Ulang, sektor Administrasi Pemerintahan, sektorPertahanan dan Jaminan Sosial Wajib, sektor Jasa Kesehatan dan Kegaiatan Sosial dan sektor Jasa Lainnya. Hal ini mengartikan bahwa pada periode tahun 2013-2017 sektor tersebut memiliki pertumbuhan yang menonjol pada tingkat provinsi namun pada tingkat kabupaten belum menonjol. Sektor ekonomi yang mempunyai nilai RPR negatif (-) dan nilai RPS negatif (-) yaitu sektor Industri Pengolahan, sektor Transportasi dan Pergudangan dan sektor Jasa Keuangan dan Asuransi. Hal ini mengartikan bahwa pada periode tahun 2013-2017 sektor-sektor tersebut memiliki pertumbuhan yang tidak menonjol pada tingkat kabupaten begitu juga pada tingkat provinsi.

Dari hasil analisis MRP dalam konteks kabupaten Labuhanbatu tersebut, menunjukkan bahwa sektor pertambangan dan pengalian dan sektor kontruksi, sektor perdagangan besar dan eceran, sektor reparasi mobil dan sepeda motor, sektor penyediaan akomodasi dan makan minum, sektor informasi dan komunikasi dan sektor real estate, sektor jasa perusahaan dan sektor jasa pendidikan merupakan sektor yang dominan pertumbuhannya. Selain itu, sektor tersebut juga menunjukkan peningkatan terhadap struktur pertumbuhan ekonomi.merupakan sektor yang dominan pertumbuhannya dan sektor-sektor tersebut menunjukkan peningkatan pada struktur pertumbuhan ekonomi. Dengan hasil ini berarti dapat dikatakan bahwa Kabupaten Labuhanbatu memiliki pertumbuhan ekonomi yang cukup baik karena sebagian besar sektor ekonomi mempunyai pertumbuhan yang menonjol.

\section{PENUTUP}

\section{Kesimpulan}

1. Hasil dari analisis Klassen Typologi dengan pendekatan sektoral, menunjukkan bahwa sektor industri pengolahan menduduki kuadran I yaitu sektor maju dan tumbuh cepat. Disusul oleh sektor pertambangan, sektor perdagangan, sektor transportasi dan sektor akomodasi pada kuadran II yaitu sektor maju tetapi tertekan. Selain dari dua sektor ini, sektor ekonomi di Kabupaten Labuhanbatu masih banyak berada pada kuadran IV yaitu sektor yang relatif tertinggal.

2. Hasil perhitungan nilai LQ diseluruh sektor perekonomian berdasarkan indikator pendapatan daerah yaitu PDRB atas dasar harga konstan 2010 terdapat lima sektor yang menjadi basis perekonomian Kabupaten Labuhanbatu yang dapat diprioritaskan menjadi sektor unggulan pada tahun 2013-2017 yaitu sektor pertanian dan sektor pertambangan dan penggalian. Hal ini menunjukkan bahwa sektor-sektor tersebut memiliki kontribusi yang besar dalam perekonomian dan pembangunan wilayah di Kabupaten Labuhanbatu. Kelima sektor tersebut memiliki nilai surplus pendapatan dan pengganda pendapatan yang positif dan cenderung meningkat.

3. Hasil analisis Shift Share, menunjukkan bahwa sektor yang merupakan sektor unggulan di kabupaten Labuhanbatu dengan kriteria tergolong ke dalam sektor basis dan kompetitif atau memiliki daya saing yang kuat di tingkat Provinsi Sumatera Utara yaitu sektor jasa- 
jasa. Sektor ekonomi Kabupaten Labuhanbatu selama Tahun 2013-2017 secara perlahan telah mengalami pergeseran dari sektor primer ke sektor tersier.

\section{Daftar Pustaka}

Arsyad, L. (2010). Ekonomi Pembangunan Edisi Kelima. Yogyakarta: UPP STIE YKPN.

Erawati. (2011). Analisis Pola Pertumbuhan Ekonomi dan Sektor Potensial Kabupaten Klungkung. Universitas Udayana

Hasani, A. (2010). Analisis Struktur Ekonomi Berdasarkan Pendekatan Shift Share di Provinsi Jawa Tengah Periode Tahun 2003-2008. Universitas Diponegoro, Semarang

Kuncoro. (2002). Evaluasi Penetapan Kawasan Andalan: Studi Empiris di Kalimantan Selatan 1993-1999. Ekonomi dan Bisnis Indonesia

Ramda, E. E., Utama, Made Suyana. (2015). Pergeseran Struktur Ekonomi Dan Potensi Kabupaten Manggarai Periode 2010-2015. Ekonomi Pembangunan

Sitohang, Paul. 2001. Dasar-dasar Ilmu Ekonomi Regional. Edisi Revisi. Fakultas Ekonomi Universitas Indonesia, Jakarta

Sjafrizal. (2008). Ekonomi Regional, Teori Aplikasi. Padang: Baduose Media

Sukirno, S. (1994). Pengantar Teori Ekonomi Makro. Jakarta: Raja Grafindo Persada

Taringan, R. (2005). Ekonomi Regional Teori dan Aplikasi Revisi. Jakarta: PT Bumi Aksara.

Todaro. (2000). Pembangunan Ekonomi Jilid 1. Jakarta: Erlangga.

Tuandali, N. F. D., Engka, Deissy S.M Wauran, Patrick C. (2014). Analisis Pergeseran Struktur Ekonomi dan Sektor Kabupaten Halmahera Utara Provinsi Maluku Utara Periode 2010-2014. Ekonomi Pembangunan

Badan Pusat Statistik, Produk Domestik Regional Bruto Atas Dasar Harga Berlaku Menurut Kabupaten/Kota di Provinsi Sumatera Utara , 2013-2018. diakses 18 Desember September 2019. https://Sumut.bps.go.id 